\title{
Organizational Agility: The Key to Organizational Success
}

\author{
Wageeh A. Nafei ${ }^{1}$ \\ ${ }^{1}$ University of Sadat City, Menoufia, Egypt \\ Correspondence: Wageeh A. Nafei, University of Sadat City, Menoufia, Egypt. E-mail: \\ dr.wageeh1965@yahoo.com
}

Received: August 10, 2015

Accepted: February 26, 2016

Online Published: April 18, 2016

doi:10.5539/ijbm.v11n5p296

URL: http://dx.doi.org/10.5539/ijbm.v11n5p296

\begin{abstract}
Background: In the current turbulent and highly competitive environment of today, OA, that is the ability of organizations to quickly sense and respond to environmental changes, is an important determinant of organization success.

Purpose: The purpose of this research is to identify the types of OA (sensing agility, decision-making agility and acting agility) and its role in promoting Organizational Success (OS) of the employees at Menoufia University Hospitals in Egypt.

Research Design/Methodology: To assess positive OA, refer to (OA questionnaire, Jaworski \& Kohli, 1993) and OS (OS questionnaire Simon et al., 2011). The data of the study was collected from the employees at Menoufia University Hospitals in Egypt. Out of the 338 questionnaires that were distributed to employees, 285 usable questionnaires were returned, a response rate of $84 \%$. Multiple Regression Analysis (MRA) was used to confirm the research hypotheses.
\end{abstract}

Findings: The researcher has found that the study subjects do agree that OA directly affects the dimensions of OS of the employees at Menoufia University Hospitals in Egypt.

Practical implications: This research helps to stimulate scientific research, particularly in terms of testing the model content, as well as studying the study variables and the factors affecting them. In addition, this research pointed to the need for organizations to practice $\mathrm{OA}$ in order to be able to meet contemporary intense competition, as this trend is to play an important role in enhancing OS.

Originality/value: This research dealt with $\mathrm{OA}$ in terms of its concept and dimensions, in addition to dealing with the role of OA in promoting OS at Menoufia University Hospitals in Egypt.

Keywords: organizational agility, organizational success

\section{Introduction}

In the beginning of the $21^{\text {st }}$ century, the world faced considerable changes in all aspects, especially great changes in the communicational channels. These changes require organizations to revise their strategic priorities and visions (Sharifi \& Zhang, 1999, 2001). The Organizational Agility (OA) is one of the methods for responding to these changes and revolution factors. Indeed, the $\mathrm{OA}$ is a new paradigm for engineering competitive organizations and firms.

Since human mind capabilities are limited in terms of grasping important changes that take place in the environment surrounding it, so has the current business environment for any organization in the world become complicated and highly dynamic (Zain et al., 2005). Therefore, it has become necessary that organizations in dire need for light movement of human capital be characterized with sensing agility, decision-making, and agility in carrying out work properly. This should be done in a manner which makes them engaged at work devoting all their efforts, feelings and realization in order to achieve the objectives of the organization (Markos \& Sridevi, 2010; Warr \& Inceoglu, 2012).

In the unpredictable and competitive world of today, the organizations must have different competitive features to compete; otherwise, they will move towards annihilation. One of these features that organizations need in the turbulent environments of today is agility. Agility provides the organization with the possibility of quick response and compatibility with environment and allows the organization to improve its efficiency (Yeganegi \& Azar, 2012). 
Continuous change is increasingly the new norm rather than the exception in contemporary organizations (Brown \& Eisenhardt, 1998). As a result, interest in OA has grown exponentially for practitioners and researchers (Tallon \& Pinsonneault, 2011).

OA has become the topic of interest of both academics and practitioners in recent years. Nine out of ten executives ranked OA as both critical to business success and growing in importance over time in a McKinsey \& Company survey (Sull, 2009).

OA plays an important role in the life of the organization as it provides personnel with knowledge, high skills, restructuring and organizational processes, employing new technology (Sherehiy, 2008).

Research on OA is emerging in the information systems field (Izza et al., 2008) due to the extensive reliance of contemporary organizations on information, in general, and information system, in particular. OA refers to organizations' ability to thrive by sensing and responding to environmental changes which has become critically important nowadays when the business environment is getting highly competitive and turbulent. It is regarded as a key business factor and a potential enabler to organization's competitiveness (Mathiassen \& Pries-Heje, 2006),

This study is structured as follows: Section one is introductory. Section two presents the literature review. Section three discusses the research methodology. Section four presents the hypotheses testing. Section five explains the research findings. Research recommendations will be found at section six. Section seven handles the research implications. Limitations and future research will take place at section eight. Conclusion will be provided at the last section.

\section{Literature Review}

\subsection{Organizational Agility}

The concept of agility needs to be well grounded in management theory (Yusuf et al., 1999). Early in the 1990s, the new solution for managing a dynamic and changing environment emerged; agility. Agile manufacturing is the ability of surviving and prospering in a competitive environment of continuous and unpredictable change by reacting quickly and effectively to changing markets, driven by customer-defined products and services (Gunasekaran, 1999).

The creators of "agility" concept at the Iacocca Institute, of Lehigh University (USA), defined it as a manufacturing system with capabilities (hard and soft technologies, human resources, educated management, information) to meet the rapidly changing needs of the marketplace (speed, flexibility, customers, competitors, suppliers, infrastructure, responsiveness). Agility is the successful application of competitive bases such as speed, flexibility, innovation, and quality by the means of the integration of reconfigurable resources and best practices of knowledge-rich environment to provide customer-driven products and services in a fast changing environment (Yusuf et al., 1999).

Agility emphasizes speed and flexibility as the primary attributes of an agile organization (Gunasekaran, 1999). An equally important attribute of agility is the effective response to change and uncertainty (Goldman et al., 1995).

Agility refers to the proactive responses to changes (Bessant et al., 2001). Agility refers to the use of changes as inherent opportunities in turbulent environment (Sharifi \& Zhang, 2001). Agility refers to the ability to survive and progress in the variable and unpredictable environment (Dove, 2001).

Organizational flexibility represents an organization's capacity to adjust its internal structures and processes in a predetermined response to changes in the environment. Adaptability underlies the fit of organizational operations to their environment while flexibility emphasizes the readiness of organizational resources and the ease of resource mobilization. The "agility" concept encompasses both flexibility and adaptability. Agility was coined in a manufacturing context-particularly in relation to flexible manufacturing systems (Christopher \& Towill, 2001).

Agility is a new concept in contemporary administrative thought. One writer has defined the process of agility in terms of the capabilities necessary to achieve light movement in the organization (Sherehiy, 2008). Agility is the ability to respond to unpredictable changes with quick response and profitability (Erande \& Verma, 2008).

Agility is an organizational ability to react quickly and effectively to an environment which can change radically (Janssen, 2010).

Agility refers to the ability of rapid and easy movement and rapid thinking with a thoughtful method. The root or origin of agility is derived from agile production and this is a concept that has been presented during later years. The agile production has been accepted as a successful strategy by producers that prepare them for a considerable performance (Mehrabi et al., 2013). 
According to the different definitions of the word agility, the concept of speed and quick response and also the concepts of group work and common goal regarding the word organization can be inferred. Agility can be defined as swiftness and quick response of a harmonious group to the changes made by the environment surrounding them in order to reach a goal (Yeganegi \& Azar, 2012).

OA is the organization's ability to respond quickly and effectively to unexpected opportunities, in addition to providing, in advance, solutions that meet potential needs (Nelson \& Harvey, 1995).

OA is the ability to survive and grow in an unexpected competitive environment of constant change through rapid response to changing markets and through meeting the desires and needs of customers, whether of products or services (Gunasekaran, 1999).

OA is the successful application of the competition rules, such as speed, flexibility, innovation and quality, through the means of integration of resources and the restructuring of best practices in the environment of technical knowledge, through the provision of services or products that meet customers' preferences in light of a rapidly changing environment (Yusuf et al., 1999).

OA is the organization's ability to work comfortably in a quickly and consistently changing and fragmented global market environment, through producing high quality and effective performance (Tsourveloudis \& Valavanis, 2002).

OA enables the organization to carry out a series of specific tasks successfully, in addition to managing the opportunities and risks in the business activities effectively (Ardichvile et al., 2003).

OA makes organizations more responsive to market trends, and faster in terms of the delivery of products and services compared to non-agile ones. OA is composed of three basic dimensions of the sensor agility, decision-making, and agility practice and application (Sambamurthy et al., 2003).

$\mathrm{OA}$ is not only "flexible" to cater for predictable changes but also is able to respond and adapt to unpredictable changes quickly and efficiently (Oosterhout et al., 2006).

OA can be viewed as the state of organizational performance in terms of flexibility and adaptability and is attainable through organization's activities. In particular, from the process-based perspective, OA is a set of processes that allow an organization to sense changes and respond efficiently and effectively in timely and cost-effective manner in the internal and external environments. Sensing refers to an organization's ability to detect, capture and interpret organizational opportunities (Seo \& Paz 2008). Responding represents an organizational ability to mobilize and transform resources to react to the opportunities that it senses (Gattiker et al., 2005; Oosterhout et al., 2006). These two capabilities must be aligned to optimally obtain OA (Overby et al., 2006).

OA is the organizational capacity to sensor response successfully to the opportunities and threats in the market in a timely manner (Overby et al., 2006). OA is a proactive management strategy that aims at maintaining the organization's resources and achieving the desires of customers in a timely manner (Hitt et al., 2007).

The concept of OA is derived from performance characteristics of an agile organization and is rooted in two related concepts- "organizational adaptability" and "organizational flexibility". Organizational adaptability focuses on how an organization's form, structure, and degree of formalization influence its ability to quickly adapt to its business environment (Sherehiy et al., 2007).

OA consists of several key elements. They are (1) speed and flexibility, (2) responding to changes in the surrounding environment, (3) high quality products, (4) products and services of accurate information, (5) interacting with social issues and the environment, (6) different technologies collecting, and (7) internal integration inside the institutions and among each other (Sherehiy, 2008).

$\mathrm{OA}$ is the process of arrangement, and abolition of business units, markets and industries to re-focus on differentiated core capabilities (Hill \& Jones, 2009).

$\mathrm{OA}$ is a package of ideas that aims at continuous improvement, flat organizational structures, work teams, stopping waste or loss, efficient use of resources, and managing the chain of preparation. Japanese companies have adopted the concept of OA in terms of reducing costs through the removal of waste (David, 2009).

OA is a construction of three basic elements. They are (1) sensing agility, (2) decision-making, and (3) acting using agility and its application (Pavlou \& El Sawy, 2010). OA quickly meets customer requests, offers new products, and gets on strategic alliances or gets rid of them. This means that organizations are in an urgent need of strategic alliances in order to solve the problems of its customers, rather than provide products or one service. The fundamental reason behind the necessity of OA is searching for the core capabilities, on the one hand, and 
identifying the business environment and capturing opportunities, on the other hand (McCarthy et al, 2010). OA is the manufacturing system for physical and non-physical technology, human resources, educated management and information in order to meet the rapidly changing needs of the market in a manner that achieves the desires and needs of the customers in time (Park, 2011).

In light of this, the researcher does identify OA as the organization's ability to achieve its objectives, through the development of its products increasing knowledge of its human resources, effecting the development of the organization and lightening its movement in a rapidly changing environment.

The dimensions of the OA are three main types. They are sensing agility, decision-making agility and acting agility (Park, 2011).

- Sensing Agility: Sensing agility is the organizational capacity to inspect and monitor events and changes in the surrounding environment (customer preferences changes, the movements of the new competitors, new technology) in a timely manner (Park, 2011). The task of sensing means the strategic monitoring of environmental events that could have an impact on organizational strategy, competitive work, and future performance, including several activities such as access to information related to the events which show environmental change, on the one hand, and getting rid of the trivial information, on the other hand, in light of predetermined foundations and rules (El-Sawy, 1985). This task is related to decision-making and its execution (Daft \& Weick, 1984; Dutton \& Duncan, 1987). It is interested in organizational adaptation to change in the surrounding environment (Smircich \& Stubbart, 1985).

- Decision-Making Agility: Decision-making agility process is the ability to collect, accumulate, restructure and evaluate relevant information according to a variety of sources to explain the implications of the business without delay, and to identify opportunities and threats based on the interpretation of events, along with the development of action plans, which direct the reconfiguration of resources and the development of new competitive procedures. The decision-making task consists of several interrelated activities, which explain many events and identify opportunities and threats in the surrounding environment. The task of decision-making focuses on collecting information from multiple and diverse sources in order to understand the implications of their work (Thomas et al., 1993). The task of decision-making seeks to capture the utmost opportunities and minimize the impact of threats on the life of the organization (Houghton et al., 2004).

- Acting Agility/Practicing: The acting task consists of a set of activities for re-assembling organizational resources and modifying business processes on the basis of the principles of work resulting from the task of decision-making in order to address the change that occurs in the surrounding environment (Eisenhardt $\&$ Martin, 2000). Organizations can change the business processes by various procedures and resources, redesigning the organizational structure of the organization (Dutton \& Duncan, 1987; Thomas et al., 1993).

\subsection{Organizational Success}

"Success" in English, according to (Webster, 1974) means "end your access to what is best, or access to exce" 1.

In French, according to (Robert, 1983) "Reussite" means getting a new result, and the means to reach or attain higher. With respect to Organizational Success (OS), there is still some confusion and lack of clarity of methodological and procedural frameworks.

Growth is an indicator for measuring OS. It means efficiency or the organization's ability to achieve its objectives in the long term, through expansion, renovation and survival (Whetten, 1987).

Regarding success through financial performance, operational productivity and efficiency, profits, target return, improvement programs in total quality management framework, re-engineering of reference and comparison is a narrow view that does not define success in the long-term in light of competitive markets. Success in the long-term lies in the organization's ability to do better things than competitors do. This is through owning distinct and fundamental capabilities that can not be imitated; besides ability to get on a competitive center of excellence (Hill \& Jones, 2001).

OS is the organization's ability to achieve long-term goals and balance between the goals and objectives of the organization of employees (Kenny, 2001).

OS is the organization's ability to coordinate activities in all components linking this to a common vision to achieve its strategic goals. (Dell \& Kramer, 2003).

The basic elements of OS may be expressed in the form of an equation: OS $=$ message + strategic goals + outstanding performance (Whitney, 2010).

There are two approaches for OS in all different organizations. The first approach to OS is the economic gateway. 
It is based on the competitive advantage stemming from the distinct market place. The first set for the performance of the organization is the external environment of the structure of the competition environment industry (Ambrosini, 2003). This includes approaches of forces of competition (Porter), innovation (Schumpeter), and scenario analysis which is characterized by a vision of the future opportunities and environmental threats, besides forecasting analysis of the competitive advantages (Grant, 2000).

The second approach to OS is based on the relatively modern resources approach, which confirms the possibility of looking at the organization as a package of resources to enable them to get a sustainable competitive advantage (Ambrosini, 2003). This approach is mainly based on a study (Selznick, 1957) about the distinctive competencies, and Penrose (1959) that the organization is a collection of resources and their performance depends on their ability to use these resources. This includes the approach of the value chain to analyze the strategic capabilities that can be converted into essential competencies that support competitive advantage analysis (Hitt, 2001).

\section{Methodology}

\subsection{Research Model}

The proposed comprehensive conceptual model is presented in Figure 1. The diagram below shows that there is one independent variable of OA. There is one dependent variable of OS. It shows the rational links among the variables. The research model is as shown in the following figure.

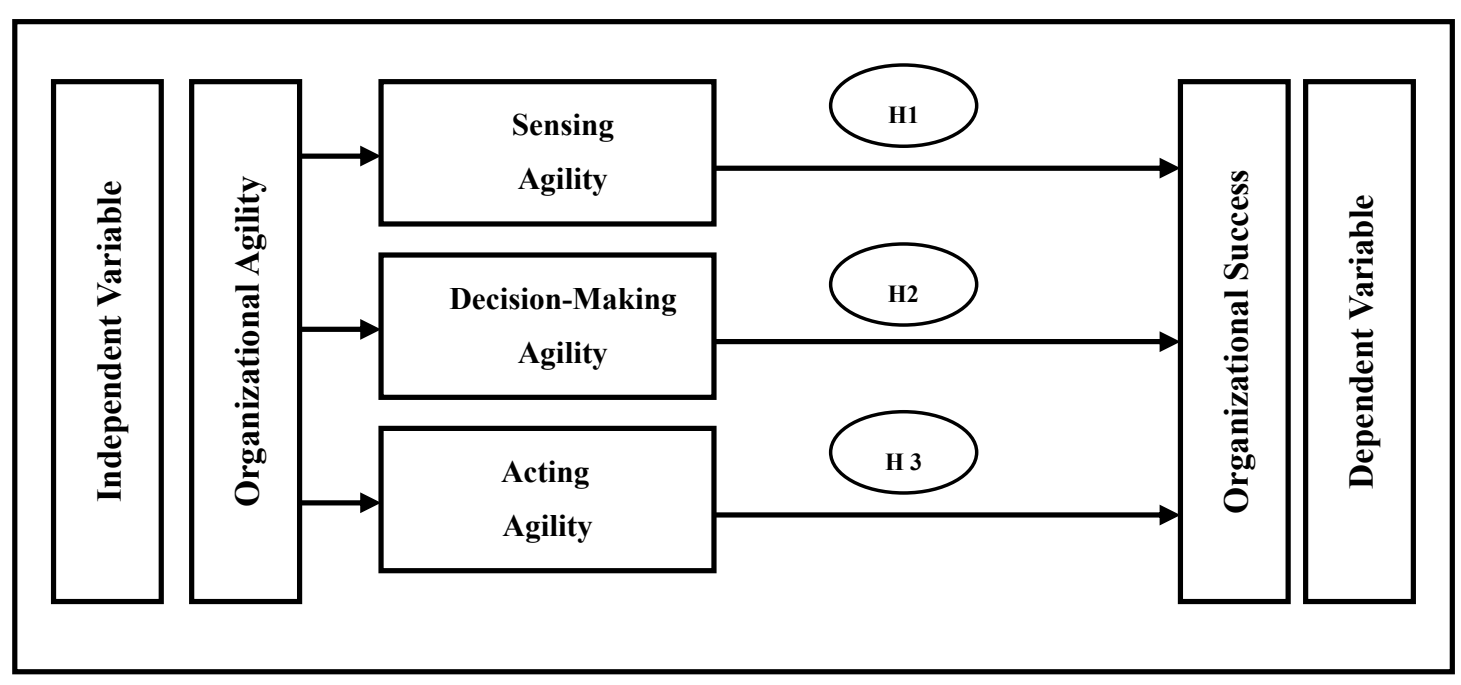

Figure 1. Proposed comprehensive conceptual model

The research framework suggests that OA has an impact on OS. OA as measured consisted of sensing agility, decision-making agility and acting agility (Jaworski \& Kohli, 1993).

Organizational success is measured in terms of organizational survival and organizational growth (Simon et al., 2011).

\subsection{Research Questions and Hypotheses}

The researcher found the research problem through two sources. The first source is to be found in previous studies, and it turns out that there is a lack in the number of literature reviews that dealt with the analysis of the relationship between OA and OS at Menoufia University Hospitals in Egypt. This called for the researcher to test this relationship in the Egyptian environment. The second source is the pilot study, which was conducted in an interview with (30) employees in order to identify the relationship between OA and OS. The researcher found through the pilot study several indicators notably the important and vital role that could be played by OA in reinforcing OS at Menoufia University Hospitals in Egypt. As a result of the discussions given above, the research questions are as follows:

Q1: What is the nature and extent of the relationship between OA (sensing agility) and OS at Menoufia University Hospitals in Egypt. 
Q2: What is the nature of the relationship between OA (decision-making agility) and OS at Menoufia University Hospitals in Egypt.

Q3: What is the extent of the relationship between OA (acting agility) and OS at Menoufia University Hospitals in Egypt.

There are studies in literature that study OA and OS factors separately and within the frame of bilateral relation but there is no study that examines these two factors collectively at the Egyptian environment. This study aims to contribute to the literature by examining the research variables collectively and reveal the interaction between the research variables.

As a result of the discussions given above, the following hypotheses were developed to test the effect of OA on OS at Menoufia University Hospitals in Egypt.

H1: OA (sensing agility) of employees has no statistically significant effect on OS at Menoufia University Hospitals in Egypt.

H2: OA (decision-making agility) of employees has no statistically significant impact on OS at Menoufia University Hospitals in Egypt.

H3: OA (acting agility) of employees has no statistically significant influence on OS at Menoufia University Hospitals in Egypt.

\subsection{Population and Sample}

The population of the study included all employees at Menoufia University Hospitals in Egypt. The total population is 2839 employees. Determination of sample size was calculated using the formula (Daniel, 1999) as follows:

$$
\mathrm{n}=\frac{N \times(Z)^{2} \times P(1-P)}{d^{2}(N-1)+(Z)^{2} \times P(1-P)}
$$

The number of samples obtained by 338 employees at Menoufia University Hospitals in Egypt in Table 1.

Table 1. Distribution of the sample size

\begin{tabular}{llll}
\hline Job Category & Number & Percentage & Size of Sample \\
\hline $1 . \quad$ Physicians & 486 & $17.1 \%$ & $338 \times 17.1 \%=58$ \\
2. Nurses & 1675 & $59.0 \%$ & $338 \times 59.0 \%=199$ \\
3. Administrative Staff & 678 & $23.9 \%$ & $338 \times \quad 23.9 \%=81$ \\
Total & $\mathbf{2 8 3 9}$ & $\mathbf{1 0 0 \%}$ & $\mathbf{3 3 8} \times \mathbf{1 0 0 \%}=\mathbf{3 3 8}$ \\
\hline
\end{tabular}

Source: Personnel Department at Menoufia University in Egypt, 2015.

Table 2 describes some of the features of the respondents at Menoufia University Hospitals in Egypt who participated in the survey.

Table 2. Frequency distribution table of demographics

\begin{tabular}{llll}
\hline Variables & & Number & Percentage \\
\hline \multirow{3}{*}{ 1. Job Title } & Physicians & 116 & $40.7 \%$ \\
& Nurses & 146 & $51.2 \%$ \\
& Administrative Staff & 23 & $8.1 \%$ \\
2.Sex & Total & $\mathbf{2 8 5}$ & $\mathbf{1 0 0 \%}$ \\
& Male & 110 & $38.6 \%$ \\
& Female & 175 & $61.4 \%$ \\
3.Marital Status & Total & $\mathbf{2 8 5}$ & $\mathbf{1 0 0} \%$ \\
& Single & 76 & $26.7 \%$ \\
& Married & 209 & $73.3 \%$ \\
4.Age & Total & $\mathbf{2 8 5}$ & $\mathbf{1 0 0} \%$ \\
& Under 30 & 113 & $39.6 \%$ \\
& From 30 to 45 & 117 & $41.1 \%$ \\
& Above 45 & 55 & $19.3 \%$ \\
& Total & $\mathbf{2 8 5}$ & $\mathbf{1 0 0} \%$ \\
\hline
\end{tabular}




\begin{tabular}{lllc}
\hline & Secondary School & 93 & $32.6 \%$ \\
5.Educational Level & University & 142 & $49.8 \%$ \\
& Post Graduate & 50 & $17.5 \%$ \\
& Total & $\mathbf{2 8 5}$ & $\mathbf{1 0 0 \%}$ \\
\multirow{2}{*}{ 6.Period of Experience } & Less than 5 years & 91 & $31.9 \%$ \\
& From 5 to 10 & 75 & $26.3 \%$ \\
& More than 10 & 119 & $41.8 \%$ \\
\hline
\end{tabular}

\subsection{Procedure}

The goal of this study was to identify the relationship between OA and OS at Menoufia University Hospitals in Egypt. A survey research method was used to collect data. The questionnaire included three questions, relating to OA, OS, and biographical information of employees at Menoufia University Hospitals in Egypt. Data collection took two months. Survey responses were 84\%, 285 completed surveys out of the 338 distributed.

\subsection{Research Variables and Methods of Measuring}

\subsubsection{Organizational Agility}

The researcher will depend on the scale developed by Jaworski \& Kohli 1993 in measuring OA, which has been divided into three elements (sensing agility, decision-making agility and acting agility). The 15 -item scale OA section is based on Jaworski and Kohli (1993). There were three items measuring sensing agility, five items measuring decision-making agility, and seven items measuring acting agility. The survey form is used as the main tool for data collection in measuring OA at Menoufia University Hospitals in Egypt.

\subsubsection{Organizational Success Scale}

The researcher will depend on the scale developed by (Simon et al., 2011), in measuring OS, which has been divided into two main components (organizational survival and organizational growth).

The 10-item scale OS section is based on Simon, et al., 2011. There were five items measuring organizational survival and five items measuring organizational growth. The survey form has been used as a key tool to collect data to measure OS at Menoufia University Hospitals in Egypt.

Responses to all items scales were anchored on a five (5) point Likert scale for each statement, ranging from (5) "full agreement," (4) for "agree," (3) for "neutral," (2) for "disagree," and (1) for "full disagreement."

\subsection{Data Analysis and Testing Hypotheses}

The researcher has employed the following methods: (1) Cronbach's alpha or ACC, (2) (MRA), and (3) F-test and T-test. All these tests are found in SPSS.

\section{Hypotheses Testing}

\subsection{Evaluating Reliability}

Before testing the hypotheses and research questions, the reliability of OA and OS were assessed to reduce errors of measuring and maximizing constancy of these scales. To assess the reliability of the data, Cronbach's alpha test was conducted.

Table 3 shows the reliability results for OA and OS. All items had alphas above 0.70 and were therefore excellent, according to Langdridge's (2004) criteria.

Table 3. Reliability of organizational agility and organizational success

\begin{tabular}{|c|c|c|c|}
\hline Variables & The Dimension & $\begin{array}{ll}\text { Number } & \text { of } \\
\text { Statement } & \\
\end{array}$ & $\mathrm{ACC}$ \\
\hline \multirow{4}{*}{$\mathbf{O A}$} & Sensing Agility & 3 & 0.6500 \\
\hline & Decision-Making Agility & 5 & 0.7622 \\
\hline & Acting Agility & 7 & 0.7898 \\
\hline & Total Measurement & 15 & 0.8914 \\
\hline \multirow{3}{*}{ OS } & Organizational Survival & 5 & 0.8763 \\
\hline & Organizational Growth & 5 & 0.9325 \\
\hline & Total Measurement & 10 & 0.9559 \\
\hline
\end{tabular}

Regarding Table 3, the 15 items of OA are reliable because the ACC is 0.8914 . Sensing agility, which consists of 
3 items, is reliable because the ACC is 0.6500 . Decision-making agility, which consists of 5 items, is reliable because the ACC is 0.7622 . Furthermore, the acting agility which consists of 7 items, is reliable because the ACC is 0.7898 . Thus, the internal consistency of OA can be acceptable.

According to Table (3), the 10 items of OS are reliable because the ACC is 0.9559 . The organizational survival, which consists of 5 items, is reliable because the ACC is 0.8763 . The 5 items related to organizational growth are reliable because ACC is 0.9325 . Thus, the reliability of OS can be acceptable.

Accordingly, two scales were defined, OA (15 variables), where ACC represented about 0.8914 , and OS (10 variables), where ACC represented 0.9559 .

\subsection{Correlation Analysis}

Table 4. Descriptive statistics and correlation matrix of constructs

\begin{tabular}{lllllll}
\hline Variables & Mean & Std. Deviation & $\mathbf{1}$ & $\mathbf{2}$ & $\mathbf{3}$ & $\mathbf{4}$ \\
\hline 1. Sensing Agility & 4.14 & 0.752 & 1 & & & \\
2. Decision-Making Agility & 3.64 & 0.801 & $0.592^{* *}$ & 1 & & \\
3. Acting Agility & 3.99 & 0.642 & $0.847^{* *}$ & $0.651^{* *}$ & 1 & \\
4. Organizational Success & 3.65 & 0.849 & $0.323^{* *}$ & $0.295^{* *}$ & $0.488^{* *}$ & 1 \\
\hline
\end{tabular}

Note. ** Correlation is significant at 0.01 level.

Based on Table 4, the first issue examined was the different facets of OA (sensing agility, decision-making agility and acting agility). According to Table 4, among the various facets of OA, those who responded identified the presence of a sensing agility $(M=4.14, S D=0.752)$. This was followed by acting agility $(M=3.99, S D=0.652)$, and decision-making agility $(M=3.64, S D=0.801)$.

The second issue examined was the different facets of OS (organizational survival, and organizational growth). Most of the respondents identified the overall OS ( $\mathrm{M}=3.65, \mathrm{SD}=0.849)$.

According to Table 4, OA dimensions have positive and significant relation with OS dimensions. The correlation between OA (sensing agility) and OS is 0.323 . For decision-making agility and OS, the value is 0.295 , whereas acting agility and OS show correlation value of 0.488 .

Finally, Table 4 proves that there is a significant and positive correlation between OA and OS. So our hypothesis is rejected and it can be said that there is a significant and positive correlation between OA and OS.

\subsection{The Relationship between $O A$ (Sensing Agility) and $O S$}

The relationship between OA (sensing agility) and OS at Menoufia University Hospitals in Egypt is determined. The hypothesis to be tested is:

\section{There is no relationship between $\mathrm{OA}$ (Sensing Agility) and OS at Menoufia University Hospitals in Egypt.}

Table 5. MRA results for OA (Sensing Agility) and OS

\begin{tabular}{|c|c|c|c|}
\hline $\begin{array}{l}\text { The Variables of OA } \\
\text { (Sensing Agility) }\end{array}$ & Beta & $\mathbf{R}$ & $\mathbf{R}^{2}$ \\
\hline $\begin{array}{l}\text { 1. The organization has been slow in terms of detecting changes that } \\
\text { occur in customer preferences for products. }\end{array}$ & $0.458^{* *}$ & 0.273 & 0.074 \\
\hline $\begin{array}{l}\text { 2. The organization has been slow to detect changes that occur in the } \\
\text { movements of competitors. }\end{array}$ & $0.371^{* *}$ & 0.418 & 0.174 \\
\hline 3. The organization has been slow to detect changes in technology. & $0.301^{* *}$ & 0.098 & 0.009 \\
\hline - MCC & 0.501 & & \\
\hline - $\quad \mathrm{DC}$ & 0.251 & & \\
\hline - $\quad$ Calculated F & 31.339 & & \\
\hline - $\quad$ Degree of Freedom & 3,281 & & \\
\hline - $\quad$ Indexed F & 3.78 & & \\
\hline - $\quad$ Level of Significance & 0.000 & & \\
\hline
\end{tabular}

Note. $* * \mathrm{P}<0.01$.

Table 5 proves that there is a relationship between OA (Sensing Agility) and OS at significance level of 0,000. As a result of the value of $\mathrm{R}^{2}$, the 3 independent variables of sensing agility can explain $25.1 \%$ of the total 
differentiation in OS level.

For the results of a structural analysis of the MRA, the direct effect of OA (sensing agility) and OS is obtained. Because MCC is $0.50 \%$, it is concluded that there is enough empirical evidence to reject the null hypothesis.

\subsection{The Relationship between OA (Decision-Making Agility) and OS}

The relationship between OA (decision-making agility) and OS at Menoufia University Hospitals in Egypt is determined. The hypothesis to be tested is:

There is no relationship between $\mathrm{OA}$ (Decision-Making Agility) and OS at Menoufia University Hospitals in Egypt.

Table 6. MRA results for OA (decision-making agility) and OS

\begin{tabular}{|c|c|c|c|}
\hline $\begin{array}{l}\text { The Variables of OA } \\
\text { (Decision-Making Agility) }\end{array}$ & Beta & $\mathbf{R}$ & $\mathbf{R}^{2}$ \\
\hline $\begin{array}{l}\text { 1. The organization analyzes important events concerning customers, } \\
\text { competitors, and technology without any delay. }\end{array}$ & $0.209^{* *}$ & 0.285 & 0.081 \\
\hline $\begin{array}{l}\text { 2. The organization detects the opportunities and threats to changes in } \\
\text { customers, competitors, and technology in time. }\end{array}$ & 0.097 & 0.166 & 0.027 \\
\hline $\begin{array}{l}\text { 3. The organization carries out a specific action plan in order to meet } \\
\text { customer needs without any delay. }\end{array}$ & 1.204 & 0.186 & 0.034 \\
\hline $\begin{array}{l}\text { 4. The organization implements a plan of action in order to respond to the } \\
\text { strategic movements of competitors without delay. }\end{array}$ & 1.204 & 0.181 & 0.032 \\
\hline $\begin{array}{l}\text { 5. The organization is implementing an action plan on how to use the new } \\
\text { technology without delay. }\end{array}$ & $0.137^{*}$ & 0.259 & 0.067 \\
\hline - $\quad \mathrm{MCC}$ & 0.341 & & \\
\hline - $\quad \mathrm{DC}$ & 0.116 & & \\
\hline - $\quad$ Calculated F & 7.351 & & \\
\hline - Degree of Freedom & 5,279 & & \\
\hline - Indexed F & 3.01 & & \\
\hline - $\quad$ Level of Significance & 0.000 & & \\
\hline
\end{tabular}

Note. ${ }^{* *} \mathrm{P}<.01 ; * \mathrm{P}<0.05$.

As Table 6 proves, the MRA resulted in the R of 0.341 . This means that OS has been significantly explained by the 5 independent variables of decision-making agility. Also, the $\mathrm{R}^{2}$ of 0.116 indicates that the percentage of the variable interprets the whole model, that is, $11.6 \%$. It is evident that the five independent variables justified $11.6 \%$ of the total factors of OS. Hence, $88.4 \%$ are explained by the other factors. Therefore, there is enough empirical evidence to reject the null hypothesis.

\subsection{The Relationship between OA (Acting Agility) and OS}

The relationship between OA (acting agility) and OS at Menoufia University Hospitals in Egypt is determined. The hypothesis to be tested is:

\section{There is no relationship between $\mathrm{OA}$ (Acting Agility) and OS at Menoufia University Hospitals in Egypt.}

Table 7. MRA results for OA (acting agility) and OS

\begin{tabular}{|c|c|c|c|}
\hline $\begin{array}{l}\text { The Variables of OA } \\
\text { (Acting Agility) }\end{array}$ & Beta & $\mathbf{R}$ & $\mathbf{R}^{2}$ \\
\hline 1. The organization can reconfigure its resources in the proper time. & $0.171^{* *}$ & 0.298 & 0.088 \\
\hline $\begin{array}{l}\text { 2. The organization can re-adjust operations carried out in a timely } \\
\text { manner. }\end{array}$ & 0.032 & 0.359 & 0.128 \\
\hline 3. The organization can use new technology in the proper time. & $0.362^{* *}$ & 0.450 & 0.202 \\
\hline 4. The organization can introduce new products in the proper time. & $0.263^{* *}$ & 0.513 & 0.263 \\
\hline 5. The organization can change prices quickly in the proper time. & 0.065 & 0.273 & 0.074 \\
\hline 6. The organization can change strategic things in the proper time. & $0.195^{* *}$ & 0.418 & 0.174 \\
\hline $\begin{array}{l}\text { 7. The organization can solve customers' needs and complaints without } \\
\text { delay. }\end{array}$ & $0.207^{* *}$ & 0.098 & 0.009 \\
\hline
\end{tabular}




\begin{tabular}{lll}
\hline - & MCC & 0.645 \\
- & DC & 0.416 \\
- & Calculated F & 28.240 \\
- & Degree of Freedom & 7,277 \\
- & Indexed F & 2.63 \\
- & Level of Significance & 0.000 \\
\hline$* \mathrm{P}<.01$. & & \\
\hline
\end{tabular}

Table 7 proves that there is a relationship between OA (Acting Agility) and OS. As a result of the value of $\mathrm{R}^{2}$, the 7 independent variables of acting agility can explain $41.6 \%$ of the total differentiation in OS level.

For the results of a structural analysis of the MRA, the direct effect of OA (acting agility) and OS is obtained. Because MCC is $0.64 \%$, there is enough empirical evidence to reject the null hypothesis.

\section{Research Findings}

The present study on analyzing the relationship between OA (sensing agility, decision-making agility and acting agility) and OS at Menoufia University Hospitals in Egypt revealed the following results:

1. There is a significant relationship between OA and OS at Menoufia University Hospitals in Egypt. In other words, sensing agility, which is an integral part of OA, significantly and positively influences OS. This is consistent with the finding that the employees who believed their organization had a sensing agility, decision-making agility and acting agility were more successful with their job. OA plays an important role in influencing OS. Also, OA contributes significantly to reinforcing OS.

2. This study concluded that the OA was positively related with OS at Menoufia University Hospitals in Egypt. In other words, OA (decision-making agility) was positively related with OS. Overall findings from this study suggested that OA does affect OS. Hence, the management at Menoufia University Hospitals in Egypt should ensure that suitable types of agility be applied in the organization through the encouragement of cooperative teamwork.

3. There is a positive relationship between the types of OA and OS of employees at Menoufia University Hospitals in Egypt. In other words, acting agility, which is an integral part of OA, positively correlated with OS.

4. OA plays an important role in influencing OS. The study pointed out that the availability of OA (sensing agility, decision-making agility, and acting agility) plays an important role in influencing the dimensions of OS. In other words, OA affects OS.

\section{Research Recommendations}

The managers at Menoufia University Hospitals in Egypt might be able to enhance OS through the following:

1. It is necessary to pay attention to the impact of the types of OA on OS for employees at Menoufia University Hospitals in Egypt and for the purpose of obtaining an effective impact of OA on OS.

2. Broader usage of the various means of sensing agility, especially detecting and attracting important business at one time. This will highly improve OS, as the field study has proved.

3. Reconstructing decision-making agility, besides paying attention to interpreting events, identifying opportunities and threats and taking the actual plans in time. The field study has proved the adverse effect of existing structures on OS.

4. Adopting more acting agility, besides reshaping organizational resources drastically and modifying business processes and the provision of services or new products to market in time. This will entail their feeling of empowerment as the field study has concluded the existence of a strong positive impact of decentralization and authority delegation on OS.

5. Managers should be more attentive towards organizational factors; especially sensing agility, decision-making agility, and acting agility. This could lead to conformity of the factors, and more success and effectiveness of the industrial sector in the community.

6. It is necessary to prioritize the order of the dimensions of OA (sensing agility, decision-making agility and acting agility) in order to achieve the goals of organizations, involved in the current study.

7. Factors that lead to OS (organizational survival and organizational growth) should be enhanced in accordance with contemporary management trends in a changing environment. 
8. Focusing on the strength of the relationship between OA and OS in light of the organizations involved to achieve the objectives of Menoufia University Hospitals in Egypt.

9. Developing and promoting trust between individuals working in the organization, since the availability of this element is a strategic and incomparable dimension. The dimension of experience is no more sufficient alone to achieve OS, but rather creating strategic movement agility and encouraging workers towards working engagement

\section{Research Implications}

Managers at Menoufia University Hospitals in Egypt might be able to improve OS through OA (sensing agility, decision-making agility and acting agility). OA also helps employees pay attention to professional standards.

OS may exist with the help of top management at Menoufia University Hospitals in Egypt. This is achieved by taking employees interests into account. Absenteeism and turnover will be lower. Productivity and profitability will be higher.

\section{Limitations and Future Research}

There are some limitations of this study. Firstly, the data was collected from employees in Egypt. Therefore, the generalization of the results must be made with caution. Secondly, the findings may not be generalized to other organizations in Egypt. Thirdly, a small sample size is used.

There are several areas for future research. They are (1) the relationship between OA and OCB, (2) the mediating variables which link OA to OP, (3) similar studies should be undertaken in other organizations in Egypt, (4) more studies should look at a comparative study of another sector such as education and tourism, and (5) future studies should examine the relationship between OA and quality of work life, and (6) future studies should examine the relationship between $\mathrm{OA}$ and organizational excellence.

\section{Conclusion}

This study attempted to investigate the relationship between OA and OS at Menoufia University Hospitals in Egypt. The study proved that there is a statistical significant relationship between OA and OS. It revealed that $\mathrm{OA}$ and $\mathrm{OS}$ are related.

Managers at Menoufia University Hospitals in Egypt may make use of the present study. It will highlight types of OA and the impact of OA on OS.

The study findings present valuable understanding for managers at Menoufia University Hospitals in Egypt regarding how to make organizations succeed in enhancing their employees, learning effectiveness, improving professional practices, and reducing turnover.

OA has an impact on OS. Top management of the organizations can enhance the dimensions of OA by developing and encouraging some facets of OS.

Menoufia University Hospitals in Egypt can increase OS by ensuring OA within their organizations. Research on OA and OS increased over the past decade. However, this rapid growth caused several problems, including the need to better understand the conceptual similarities between various forms of OA and OS, as well as their antecedents and consequences. Overall, this is an exciting and dynamic field of research, and we hope this paper will help speed progress in this area by highlighting several key issues that need more attention.

\section{References}

Ambrosini, V. (2003). Tacit and Ambiguous Resource as Source of Competitive Advantage. UK: Palgrave Macmillan. http://dx.doi.org/10.1057/9781403948083

Ardichvili, A., Cardozob, R., \& Rayc, S. (2003). A Theory of Entrepreneurial Opportunity Identification and Development. Journal of Business Venturing, 18, 105. http://dx.doi.org/10.1016/S0883-9026(01)00068-4

Bessant, J., Knowles, D., Francis, D., \& Meredith, S. (2001). Developing the Agile Enterprise, Agile Manufacturing: The 21 st century competitive strategy.

Brown, S., \& Eisenhard, K. (1998). Competing on the Edge. Boston, MA: Harvard Business School Press.

Christopher, M., \& Towill, D. (2001). An Integrated Model for the Design of Agile Supply Chains. International Journal of Physical Distribution \& Logistics Management, 31(4), 235-246. http://dx.doi.org/10.1108/09600030110394914

Daft, L., \& Weick, E. (1984). Toward a Model of Organizations as Interpretive Systems. Academy of Management Review, 9, 284-295. 
David, F. (2009). Strategic Management-Concepts and Cases (12th ed.). Prentice-Hill Pearson Education International Inc. U.S.A.

Dell, D., \& Kramer, R. (2003). Forging Strategic Business Alignment. The Conference Board.

Dove, R. (2001). Responsibility: The language, structure, and culture of the agile enterprise. New York: Wiley

Dutton, J., \& Duncan, R. (1987). The Creation of Momentum for Change through the Process of Strategic Issue Diagnosis. Strategic Management Journal, 8, 279-295. http://dx.doi.org/10.1002/smj.4250080306

Eisenhardt, M., \& Martin, J. (2000). Dynamic Capabilities: What Are They? Strategic Management Journal, 21, 1105-1121. http://dx.doi.org/10.1002/1097-0266(200010/11)21:10/11<1105::AID-SMJ133>3.0.CO;2-E

El Sawy, O. (1985). Personal Information Systems for Strategic Scanning in Turbulent Environments: Can the CEO Go Go-Line? MIS Quarterly, 9(1), 53-60. http://dx.doi.org/10.2307/249273

Erande, A., \& Verma, A. (2008). Measuring Agility of Organizations - A Comprehensive Agility Measurement Tool (CAMT). Old Dominion University, Proceedings of The 2008 IAJC-IJME International Conference.

Gattiker, T., Chen, D., \& Goodhue, D. (2005). Agility through Standardization: A Crm/ Erp Application. In F. R. Jacobs \& B. E. (Eds.), Strategic Erp Extension and Use (pp. 87-96.). Stanford Business Books.

Goldman, S., Nagel, R., \& Preiss, K. (1995). Agile Competitors and Virtual Organizations: Strategies for Enriching the Customer. New York: Nostrand Reinhold.

Grant, R. (2000). Contemporary Strategy Analysis. Oxford, UK.

Gunasekaran, A. (1999). Agile Manufacturing: A Framework for Research and Development. International Journal of Production Economics, 62, 87-105. http://dx.doi.org/10.1016/S0925-5273(98)00222-9

Hill, C., \& Jones, G. (2001). Strategic management Theory. New York, USA: Houghton Miffin Co.

Hill, C., \& Jones, G. (2009). Strategic Management: An Integrated approach (13th ed.). Boston: Houghton Mifflin Company.

Hitt, M. A., Hoskisson, E. R., \& Ireland, R. D. (2007). Management of Strategy: Concepts and Cases. New York: South-Western.

Houghton, R., El Sawy, O. A., Gray, P., Donegan, C., \& Joshi, A. (2004). Vigilant Information Systems for Managing Enterprises in Dynamic Supply Chains: Real-Time Dashboards at Western Digital. MIS Quarterly Executive, 3(1), 19-35.

Izza, S., Imache, R., Vincent, L., \& Lounis, Y. (2008). An Approach for the Evaluation of the Agility in the Context of Enterprise Interoperability. Enterprise Interoperability, 3, 3-14. http://dx.doi.org/10.1007/978-1-84800-221-0_1

Janssen, L. (2010). Organizational agility in an institutional context.

Jaworski, B., \& Kohli, A. (1993). Market Orientation: Antecedents and Consequences. Journal of Marketing, 57(3), 52-70. http://dx.doi.org/10.2307/1251854

Kenny, G. (2001). Strategic Factor: Developing and Measure Winning Strategy (1st ed.). President Press, National Library of Australia.

Markos, S., \& Sridevi, M. (2010). Employee Engagement: The Key to Improving Performance. International Journal of Business and Management, 5(12).

Mathiassen, L., \& Pries-Heje, J. (2006). Business Agility and Diffusion of Information Technology. European Journal of Information Systems, (15), 116-119. http://dx.doi.org/10.1057/palgrave.ejis.3000610

McCarthy, I., Lawrence, T., Wixted, B., \& Gordon, B. (2010). A Multidimensional Conceptualization of Environmental Velocity. Academy of Management Review, 35(4), 604-626. http://dx.doi.org/10.5465/AMR.2010.53503029

Mehrabi, S., Siyadat, S., \& Allameh, S. (2013). Examining the Degree of Organizational Agility from Employees' Perspective (Agriculture-Jahad Organization of Shahrekord City). International Journal of Academic Research in Business and Social Sciences, 3(5), 315-323.

Nelson, A., \& Harvey, F. (1995). Technologies for Training and Supporting Your Agile Workforce. In Creating the Agile Organization: Models, Metrics and Pilots. $4^{\text {th }}$ Agility Forum Annual Conference.

Oosterhout, M. V., Waarts, E., \& Van Hillegersberg, J. (2006). Change Factors Requiring Agility and 
Implications for It. European Journal of Information Systems, 15(2), 132-145. http://dx.doi.org/10.1057/palgrave.ejis.3000601

Overby, E., Bharadwaj, A., \& Sambamurthy, V. (2006). Enterprise Agility and the Enabling Role of Information Technology. European Journal of Information Systems, 15(2), 120-131. http://dx.doi.org/10.1057/palgrave.ejis.3000600

Park, Y. (2011). The Dynamics of Opportunity and Threat Management in Turbulent Environments: The Role Information Technologies. Doctor Dissertation.

Pavlou, P., \& El Sawy, O. (2006). From IT Leveraging Competence to Competitive Advantage in Turbulent Environments: The Case of New Product Development. Information Systems Research, 17(3), 198-227. http://dx.doi.org/10.1287/isre.1060.0094

Robert, P. (1983). Brodard Et Taupin. Paris. France.

Sambamurthy, V., Bharadwaj, A., \& Grover, V. (2003). Shaping Agility through Digital Options: Reconceptualizing the Role of Information Technology in Contemporary Firms. MIS Quarterly, 27(2), 237-263.

Seo, D., \& Paz, A. (2008). Exploring the Dark Side of Is in Achieving Organizational Agility. Communication of the ACM, 51(11), 136-139. http://dx.doi.org/10.1145/1400214.1400242

Sharifi, H., \& Zhang, Z. (1999). A methodology for achieving agility in manufacturing organisations.An introduction. International Journal of Production Economics, 62(1-2), 7-22. http://dx.doi.org/10.1016/S0925-5273(98)00217-5

Sharifi, H., \& Zhang, Z. (2001). Agile Manufacturing in Practice. Application of a Methodology. International $\begin{array}{llll}\text { Journal of Operations \& Production Management, 21(5), 772-794. } & \text {. }\end{array}$ http://dx.doi.org/10.1108/01443570110390462

Sherehiy, B. (2008). Relatioships Between Agility Strategy, Work Organization and Workforce Agility. Doctor Dissertation, University of Louisville.

Sherehiy, B., Karwowski, W., \& Layer, J. (2007). A Review of Enterprise Agility: Concepts, Frameworks, and Attributes. International Journal of Industrial Ergonomics, 37(5), 445-460. http://dx.doi.org/10.1016/j.ergon.2007.01.007

Simon, A., Kumar, V., Schoeman, P., Moffat, P., \& Power, D. (2011). Strategic capabilities and their relationship to organizational success and its measures: Some pointers from five Australian studies. Management Decision, 49(8), 305-1326. http://dx.doi.org/10.1108/00251741111163133

Smircich, L., \& Stubbart, C. (1985). Strategic Management in an Enacted World. Academy of Management Review, 10(4), 724-736.

Sull, D. (2009). How to Thrive in Turbulent Markets. Harvard Business Review, 87(2), 78-88.

Tallon, P. P., \& Pinsonneault, A. (2011). Competing perspectives on the link between strategic information technology alignment and organizational agility: Insights from a mediation model. MIS Quarterly, 35, 463-486.

Thomas, J., Clark, S., \& Gioia, D. (1993). Strategic Sensemaking and Organizational Performance: Linkages among Scanning, Interpretation, Action, and Outcomes. Academy of Management Journal, 36(2), 239-270. http://dx.doi.org/10.2307/256522

Tsourveloudis, N., \& Valavanis, K. (2002). On the Measurement of Enterprise Agility. Journal of Intelligent \& Robotic Systems, 33(3), 329-342. http://dx.doi.org/10.1023/A:1015096909316

Warr, P., \& Inceoglu, I. (2012). Job Engagement, Job Satisfaction, and Contrasting Associations with Person-Job Fit. Journal of Occupational Health Psychology, 17(2), 129-138. http://dx.doi.org/10.1037/a0026859

Webster's Merriam Co. (1974). USA.

Whetten, D. (1987). Organizational Growth and Decline Processes. Annual Review of Sociology, 13, 335-358. http://dx.doi.org/10.1146/annurev.so.13.080187.002003

Whitney, D. (2010). Appreciative Inquiry: Creating Spiritual Resonance in the Workplace. Journal of Management, Spirituality \& Religion, 1-21. http://dx.doi.org/10.1080/14766080903497656 
Yeganegi, K., \& Azar, M. (2012). The Effect of IT on Organizational Agility. Proceedings of the 2012 International Conference on Industrial Engineering and Operations Management, Istanbul, Turkey.

Yusuf, Y., Sarhadi, M., \& Gunasekaran, A. (1999). Agile Manufacturing: The Drivers, Concepts and Attributes. $\begin{array}{lllll}\text { International Journal of Production } & \text { Economics, }\end{array}$ http://dx.doi.org/10.1016/S0925-5273(98)00219-9

Zain, M., Rose. R., Abdullah, I., \& Masrom, M. (2005). The Relationship between Information Technology Acceptance and Organizational Agility in Malaysia. Information \& Management, 42, 829-839. http://dx.doi.org/10.1016/j.im.2004.09.001

\section{Copyrights}

Copyright for this article is retained by the author(s), with first publication rights granted to the journal.

This is an open-access article distributed under the terms and conditions of the Creative Commons Attribution license (http://creativecommons.org/licenses/by/3.0/). 